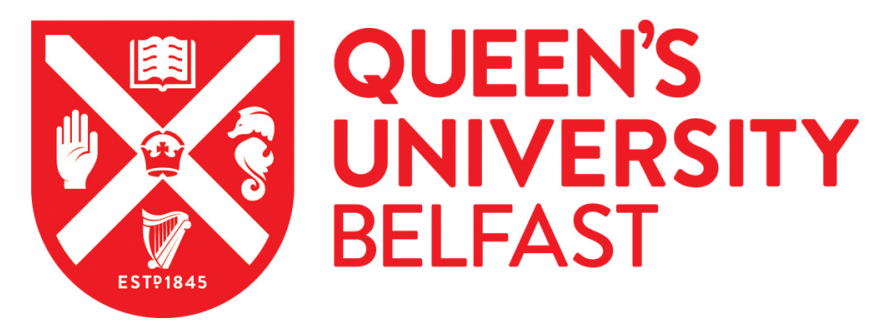

\title{
Denominations as (Theological) Institutions: An Afterward
}

Webster, J. (2019). Denominations as (Theological) Institutions: An Afterward. Anthropological Quarterly. https://doi.org/10.1353/anq.2019.0063

Published in:

Anthropological Quarterly

Document Version:

Peer reviewed version

Queen's University Belfast - Research Portal:

Link to publication record in Queen's University Belfast Research Portal

Publisher rights

Copyright 2019 George Washington University, Institute for Ethnographic Research. This work is made available online in accordance with the publisher's policies. Please refer to any applicable terms of use of the publisher.

\section{General rights}

Copyright for the publications made accessible via the Queen's University Belfast Research Portal is retained by the author(s) and / or other copyright owners and it is a condition of accessing these publications that users recognise and abide by the legal requirements associated with these rights.

Take down policy

The Research Portal is Queen's institutional repository that provides access to Queen's research output. Every effort has been made to ensure that content in the Research Portal does not infringe any person's rights, or applicable UK laws. If you discover content in the Research Portal that you believe breaches copyright or violates any law, please contact openaccess@qub.ac.uk. 


\section{The Difference Denominations Make}

\section{Anthropological Quarterly Special Issue}

\section{Denominations as (Theological) Institutions: An Afterward}

When is a church a church? What makes a church a denomination? What makes a denomination an institution? And what constitutes that institution: people, the law, money, divine approval, or something else? In asking questions such as these, Handman, Opas, Hardin, and MacLochlainn usefully address denominational forms as institutions, which has long been a sociological concern, most especially in the work of Goffman (1961), but has arguably received comparatively little attention within the anthropology of Christianity. Taken together, then, the papers by these authors address not just questions about form and function, but also questions about how the self becomes built into structures that regard rules and norms as an important, even sacred expression of Christian life and truth.

The collective specificity of the ethnographic cases that we have been presented with is hard to miss: Lutheranism in New Guinea, Pentecostalism in Samoa, Methodism in the Philippines, and Evangelicalism and Pentecostalism in Amazonia. Importantly, when Catholicism does make an empirical appearance, it is very often described in the context of its largely negative interpretation by non-Catholic (and often anti-Catholic) Christians. As such, it seems fair to begin by asking whether or not these papers address the Anthropology of Christianity, or actually the Anthropology of Protestantism? More than this, are we actually talking about a specific kind of high-density, experientially intense Pentecostalism and Evangelicalism? To be clear, this observation need not be read as a critique, at least not as previously formulated by Hann (2007) in relation to what he calls 'The Anthropology of Christianity per se'. Instead, the striking denominational (or perhaps, typological) similarity I find in these papers' ethnographic cases may be read as a strength rather than a weakness.

This seems true insofar as the kind of ethnographic comparison I attempt below is able to proceed on a surer footing, given that some (but certainly not all) of the emic theological assumptions at play 
appear to be held in common. The tense relationship between Protestant ecclesiology and soteriology, for example, emerges as a trend across all four papers. If anything is to be gained analyitically by echoing the concerns of our informants (and I think there is) then we might venture to pose a theological question such as: is religious division the product of the sins of pride, greed, and idolatry, or are such divisions the result of a godly insistence on the singularity of biblical truth? Rephrased anthropologically, we might ask what are the institutional forms of Protestantism, and what differences do these forms make?

To this end, Courtney Handman's paper examines the colonial and more recent history of Christian mission in PNG, whereby denominational competition is both an empirical reality and an embarrassing and self-contradictory theological problem. Examining the strikingly self-aware commentaries of Lutheran missionary John Kuder, Handman shrewdly points out how denominational difference both matters a great deal, and is seen as a product of unspiritual division - a division that is seen to undermine the universal claims of the gospel of salvation. Here, we are confronted with the Lutheran problematic of deciding whether the gospel of salvation is to be framed within denominational specificities or within a pan-Christian attachment to the person and work of Christ. While Kuder would surely want to claim the latter, it seems that the former keeps asserting itself in a context where disagreements with other groups calling themselves Christians forces these missionaries to make sense of who they are and what their message is, but always in relation to what they are not and what their mission is not. Crucial to this is Handman's equally important observation that all this has a deeply paternalistic tone, namely that the children (that is, the natives) shouldn't see the parents (that is the denominationally divided missionaries) fighting. More than this, such a paternalistic desire for pubic unity is further coloured by assertions of authority and higher truth claims, whereby "Father definitely knows best".

But why this shame about denominationalism? My sense is that this emerges from something within the Protestant tradition in the way that truth is imagined to be formulated in a highly singular manner - a point I will also make in relation to MacLochlainn's paper. Here, denominations are (normatively) imagined to emerge from doctrinal disagreements, that is to say, Christians have licence to fall out over spiritual truth claims, but little else. The prototypical case of Luther nailing his 95 thesis to the front of All Saints Church in 1517 gives the Reformation its origin myth - a myth that sits proudly, if awkwardly, with the ethnographic reality of Protestant schismogenesis. This truth 
claim (about the singularity of truth) may have appeared persuasive when there was still a relatively coherent sense of Protestant unity, but of course, this unity had a limited shelf life, if it ever existed at all. Fast forward to Kuder in 1959, and it seems that Protestantism is ashamed of multidenominationalism because such Protestants generally hold to the claim that doctrinal truth should be singular. The ethnographic (and theological) claim, simply put, is that singular truth should produce a single Protestant denomination, but it does not, because people squabble about worldly things which have little defining purchase on truth, and this is shameful.

In my own fieldwork among the Brethren of Gamrie (Webster 2013), not only was denominational difference held to be shameful, but also potentially demonic, whereby the devil sows discord among God's saved people - a simple divide and conquer tactic. I wonder if this same logic would find any resonance among Handman's informants? How might this relate to PNG complains about racial and linguistic difference? I am reminded here of how my own informants interpreted the Tower of Babel narrative of Genesis 11, whereby linguistic difference was said to be created by God to act as a divine safeguard against humanity's self-destructive hubris. As such, the Brethren of Gamrie feared not linguistic difference but rather a return to linguistic commonality, with European efforts to promote Esperanto as a 'universal language' being viewed by some dispensationalist Christians as further evidence that the EU was indeed the antichrist.

Clearly, the irony Handman points to - that creating a Lutheran institution is seen as a legitimate way to fight the evil intuitionalism of the Catholic Church - indicates the implacable importance of the denomination. Indeed, no matter how hard humans try and escape from institutionalism by escaping into Spirit, the power of structure seems inevitably to reassert itself in complex ways. Here, I wonder whether Protestant denominationalism becomes a kind of Protestant mediation - where not only the Spirit of God, but also the structure of God is made manifest? Of course, in other contexts, these quintessentially Protestant double-binds become focused on the problematic materiality of mediation, be it the physicality of the Bible in the context of a 'live and direct' faith (Engelke 2007) or the disappearance of mining wealth from a town dominated by Prosperity churches (Haynes 2013).

Minna Opas' paper explores similar themes about denominational proliferation, and does so in a context where religious diversity is not only an institutional reality, but also a feature of the lives of 
particular persons and their wider communities. The article itself is framed by the fascinating suggestion that "it is at the denominational (and religious) boundaries, where much Christianity happens". Among the Yine people, denominations are simultaneously of great significance, and yet can be dropped, abandoned, and then taken up again with seeming ease. Crucially, doing so seems a normal and proper course of action for the Yine. While this surely seems odd and even insincere to the causal Euro-American-Protestant observer, Opas rightly points out how such a reaction is symptomatic of a profound misunderstanding of how the Yine understand themselves as relational beings.

Opas' empirical cases helpfully bring Catholicism into the conversation here, not as some kind of singular religious 'other' but as a religious other that relates to and within multiple layers of evangelicalism and Pentecostalism. Yine Catholics, for example, find themselves being sharply critiqued as drunkards, sexually immoral, and practitioners of witchcraft. This ethnography is hugely insightful, and left me wondering if, as well as denominationalism, the papers presented in this Special Issue are also necessarily addressing the issue of sectarianism? Another simple question here might be, what, if anything, is the difference between denominationalism and sectarianism? Is the difference an emotional one? Is denominationalism about begrudging tolerance, whereas sectarianism is borne out of hate? Do we see expressions of hate in claims that Catholic primary school teachers might be an agent of the Antichrist? Or is this simply a way of expressing the enchanted nature of denominational difference?

My own ethnographic research among the Orange Order across Scotland's Central Belt (Webster 2015, Forthcoming) suggests how a single social group can embrace multi-denominationalism and yet simultaneously embrace a strictly singular sectarian agenda. I met Presbyterians, Methodists, Anglicans, Congregationalists, and independent evangelicals within the ranks of the Scottish Orange Order, and many leading Orangemen were proud of the fact that, in their understanding, Protestant denominational differences had been overcome by the unifying power of Protestant fraternalism. Yet, while intra-Protestant denominational differences were downplayed within the Order, other differences - most especially between Protestants and Catholics - were maximised at every opportunity, in their constructions of British history, in private initiation rituals, in public parading, in Social Club interactions, and in the politics of the Order's campaign against Scottish independence. For some Orangemen, such efforts justified embracing hate as a moral good - definable as a moral 
good, I was told, due to the political and religious malevolence said to exist within the denomination of the Catholic Church as an 'unholy Roman Empire' dedicated to destroying both British unionism and British Protestantism.

Using this Scots-Orange case as an axis for comparison, Opas' descriptions of denominationalism as boundary-work becomes even more insightful. She rightly points out that denominations are often understood in relation to doctrinal difference. My question here, in the Yine case, is how might one be an active member of several denominations at the same time? Could one take mass in the morning, go to an evangelical bible study in the afternoon, and a Pentecostal revival meeting in the evening? The answer is surely yes. But could one do these things with equal institutional membership and affiliation? I find this harder to imagine in any context, but especially in a ScotsOrange context, were members will be expelled from the Order if they ever attend a christening, wedding, or funeral mass of a Catholic friend or family member. Equally, if for the Yine, such denomination-hopping happens not within a single day, but rather over a period of years, then perhaps this speaks again to the enduring power of institutions whereby one can change institutions, but not like a pair of socks.

This may also help explain why denominationalism seemed to matter a great deal when examined at the level of the collective, but mattered less at the level of the individual. In this context, Opas' use of the term 'thickenings' left me wanting to know more. Is this comparable to the image of a venn diagram of overlapping circles, with the point on the diagram under consideration constantly shifting - now closer, and now further away - in relation to its various boundary lines? Whatever the case, that the Yine have a "reluctance to fix the relation" is certainly an intriguing one, where, just as the body is an unstable condition, so too is denominationalism. Such reluctance is not at all found among the Brethren or among Orangemen, who both spend considerable time and effort defining themselves and others (be they the 'unsaved' or 'Catholics') as being 'fixed' in the strongest possible terms, often along theological lines, but also by deploying ideas about ethnicity. Among Brethren and Orange Protestants, then, stability is emphasised over instability, just as fixity is emphasised over fluidity. Opening up the analysis here to Yine theological understandings of the church, might such disagreements offer new perspectives on the notion of the church as the body of Christ - surely one of the most unstable bodies there ever was? 
Scott MacLochlainn's paper is also concerned with the difficult of achieving denominational fixity, and does so by bringing mammon centre stage. His empirical focus examines the complex legal twists and turns of a schism within the United Methodist Church in the Philippines, a process, we are told, which involved not only acrimonious litigation, but also sporadic physical violence. As such, his paper offers us a series of reflections on the forms and functions of Christian bureaucracy through a consideration of the (sometimes more and sometimes less) tense relationship that Protestants posit between the corporate and the divine, and between property and denominational identity.

An ethnographic vignette presented early on in the paper insightfully sets up this problematic, when Pastor Fel, a key informant of MacLochlainn's, comments that in the context of the schism between the UMC and the AIMP, "It's not easy to tell who the church is right now". That MacLochlainn adds 'or indeed... what the church is' clarifies what is at stake, namely not just issues of denominational identity, but also of existential essence and sacred mission - and here we might also add a third question, namely why the church is. MacLochlainn's answer to the 'what' question, namely that litigation between these two ecclesiastical entities helps clarify how anthropologists might best understand a denomination as a 'religious corporation', posits how the former is always intertwined with issues of bureaucracy and agency in ways that may make Methodists and anthropologists alike feel disorientated, if not squeamish. For Filipino Methodists, such squeamishness seems to be triggered by a recognition that a denomination is (potentially) definable not as a divine entity, but as a legal one. The links here with Handman's analysis of Lutheran embarrassments about denominational competition are copious, yet the Methodist case is marked by greater publicity, and thus, one could imagine, even greater embarrassment.

Regardless of the differences, a common question emerges, namely can a denomination be fully definable as a human institution? While this may well be true in the eyes of the Filipino State, I wonder if comparative ethnographic cases might suggest that the opposite could also be true? Both the Brethren and the Jehovah's Witnesses, for example, view all politics as a sphere of demonic activity, and neither groups vote as a matter of conscience as a result. In this dispensationalist worldview, the political and legal systems which exercise official bureaucratic oversight over churches are thought to be irredeemably fallen, rendering their pronouncements over who is (and is not) the 'real' church spiritually invalid, if still economically costly. What, then, might this say about how different denominations (within and outside Protestantism) regard religious corporatism as 'a 
mediating form of their community', or 'the community itself'? Could a third option be possible could such corporatism be regarded as an evil imposition and an apocalyptic sign that, during these 'last days' many churches will be tricked into bowing down to godless governments who are (literally) hell-bent on imposing their soul-ruining demonic bureaucracies? That the UMC and AIMP do not seem to think so makes the question all the more intriguing, and exploring why some denominations embrace validation by the State (while others shun it) an anthropological puzzle surely worth exploring.

Yet, MacLochlainn's paper also shows how battles over who gets to define who (and what) the 'real' church is, is something that Christians engage in between themselves, within their denominational silos, just as much as it is something that is legally imposed from the outside. Here, judgement comes not from courts, but from pastors and lay people who find their denominational sympathies pulled in different directions. The bureaucratic processes are indeed complex, with denominations and break-away denominations setting up conferences and counter conferences, with legal, financial, and institutional consequences. The question this left me with was are bureaucracies (as zero-sum games) ever non-violent? Is the changing of locks, the occupation of property, the smashing of furniture, or the choking of a pastor from a rival church simply an extension of the intended function of a legal bureaucracy specifically designed to make agreeing to disagree impossible? What are the similarities and differences here with the violent history of Christian colonialism, which all the papers address, either directly or indirectly? Other examples of broadly non-religious bureaucracies come to mind - airport security, investment banking, deep sea fishing all of which seem marked by hard-to-escape violent tendencies. What, then, is unique here about the religion of violent bureaucracies? When 'organizational forms are indeed sacred', are the costs of attempting (and failing) to agree to disagree heightened further?

In the Filipino case, much of this seemed to hinge on who had 'the full support' of both church Judicial Councils and the law courts. Yet, in reading MacLochlainn's account, I was struck again by how very different this was from Gamrie Brethren attitudes to the morality of ecclesiology, whereby, despite highly frequent denominational schism (leading to six churches in a village of 700 people), what captured the attention of my informants was not disagreements over bureaucratic due process, but rather disagreements over theology, and especially eschatology. Intriguingly, this eschatological lens still maintained a fiercely litigious emphasis, albeit one which replaced State 
actors with the end-times 'Judgement Seat of Christ'. Perhaps we see here the emergence of an emic critique not only of 'dirty politics' (Blom Hansen 2000) but also of dirty law? On this point, while I recognise the relevance of MacLochlainn's opening quote from 1 Corinthians 11:18 on division in the church, I wonder what his informants made of another Pauline warning from the same book, against disputing believers who 'go to law before the unjust' (1 Corinthians 6:1). In the context of Filipino Methodism, what precisely were MacLochlainn's informants 'aghast' at, what could they accept, and why? What, in other words, constituted (bureaucratically and religiously) 'acting in bad faith'? While I don't have any clear answers here, my suspicion is that by attending more closely to the theological parameters of these values judgements, we stand to learn even more about the relationship between religions-as-corporations and religions-as-religions.

Clearly, as MacLochlainn is right to point out, anxieties about religious bureaucracy as an impediment to unmediated (and thus ostensibly 'true') spirituality is a very Protestant concern - a point Hnadman also makes clear in her paper. But is this predilection best understood as a matter of 'backgrounds and foregrounds', or, depending on context, could this be a matter of different types of foregrounds, where, in the Protestant consciousness, something is either said to matter greatly, or else its relevance (and sometimes even its existence) is denied altogether? During my fieldwork in Gamrie, I came into contact with a restorationist Christian group referred to locally both as Cooneyites and the Northern Lights. This group stated that they were not a church, had no church buildings, and refused to take any institutional name for themselves whatsoever. They also stringently rejected any historical account of their group which did anything but link them directly back to the Early Church of the New Testament - to the point where members would routinely deny any knowledge of their founder William Irvine. In this example, then, the analytical purchase of 'backgrounds' seems to be called into question, as does the very existence of bureaucracy. Can a church that has no name, no property, and denies that it is a church, be a church? If MacLochlainn's analysis about religious corporations in the Philippines tells us anything, it is that the answer to this question is most likely no.

Jessica Hardin's paper again brings the relationship between denominationalism and mammon centre stage, adding in the additional and fascinating case of bodily health. Among Pentecostal pastors, their wives, and their congregations, money brings both this-worldly and other-worldly freedom, but in ways that always threaten to harm the faithful believer. I am struck by how perfectly 
opposite this seems to certain strands of the Catholic monastic tradition, where vows of poverty produce worldly and other-worldly freedom. In Samoa then, people previously served God's church with their labour, but now they tend to serve by giving gifts of cash. The implications are profound, not only for the soul, but also for the body.

The key to all this, Hardin explains, is the human will. Those who are forced by a greedy church to give financially become ill - and many seriously so - in the form of metabolic disease. This observation was fascinating, and provoked many questions. How precisely are such diseases imagined to take hold? In what sense is the cause and cure (very literally) a denominational one? Why are certain churches deemed 'mainline', and how do these institutional entities respond to the critiques of (and personnel loss to) Pentecostal groups? Comparative ethnographic data within the Anthropology of Christianity seems to offer an intriguing point of divergence here, where the Prosperity Gospel has been shown to offer new cultural logics of spending-giving-way-to-riches. Coleman's (2000) ethnography of the Word of Life church in Sweden, for example, details how members 'spend forward', for example by buying an expensive new business suit on a credit card in advance of a job interview. For the job candidate, such an act of spending forward (notably by sending money on themselves) by buying a suit they could not afford acted to demonstrate faith in God, who would reward such an act by giving them the job, thereby latterly allowing them to afford the suit via a newly secured increased wage. What Hardin seemingly offers, then, is not an account of the 'health and wealth' gospel its inversion, namely a disease and poverty gospel.

Intriguingly, alongside Hardin's profiling of the emic critique of mainline churches as overly acquisitive seems to lie another possible but rather different critique, namely that Pentecostal churches actually offer a model of religious gift giving that is far more constraining than that of the mainline churches insofar as what they require is both the act of gift giving, and a transformed will that desires to give. Here, the church not only wants financial support, but also wants its members to want to give. If all this seems rather Foucaultian, then perhaps it is. The conclusion of Hardin's paper nods in this direction, but not unambiguously so. 'Freedom discourses', Hardin tells us, 'forms a critique of possibility'. What we see here is how such discourses puts health and illness, as well as salvation and damnation, within the realm of choice and control, yet in a way that never turns its back on the importance of the denomination. The question this leaves me with concerns where to locate this importance? Where then, is the denomination to be found? What Hardin's paper shows 
us is that this may be located in all sorts of places at once - in one's soul, yes, but also in one's arms and legs, ones kidneys, and also, crucially, in one's wallet. The other authors in the Special Issue offer their own answers to this question too - for Handman the denomination seems (in part) to lie in the history of colonialism, as well as in the guilt that Christian institutional differences provoke. For MacLochlainn, the denomination rests in courts of law, and in the (religious and ostensibly secular) bureaucracies which laws foster. For Opas, denominations are found in the constantly shifting boundaries of restless allegiances, and in the no less restless relations that exist alongside them. I would only add here my sense that much denominationalism exists within theological commitments which exist across much of this terrain - in the minds and words of Pastors and lay people, in sacred texts and in the 'subordinate standards' of doctrinal statements, in church conferences, and in the lived connections between the 'ideas' which church affiliation provoke, and the embodied commitments which they demand.

This Special Issue has set out to ask the question: "what is lost when the sociality of Christian practice is deferred?" My own, I hope not too glib answers, is that nearly everything is lost. If the very early anthropological work of Marcel Mauss and Robert Hertz tells us anything, it is that religion is fundamentally a social phenomenon, but one that also exists in shared (that is collectively believed) 'representations', or what some call 'theologies'. But these papers have obviously pushed us beyond this simplest of Durkheimian truisms. This is certainly what is required if we are to engage carefully with the key trope of these papers, which, as I have understood it, is about the denomination not only as a kind of society, but also as an social institution.

Lastly, although all four papers are unapologetically anthropological (and rightly so), it seems that they offer more than a macro reflection on several classic social anthropological themes including boundaries, personhood, structure, giving, agency, and mediation. Indeed, by taking the empirical focus on denominationalism as not only an ethnographic concern, but also a theoretical one, a key (but perhaps unintended) insight of these papers is how studying the lived experiences of our Christian informants might reveal to us the socially formative force of theology. Several new questions sprout from this emerging dialogue between the anthropological and the theological (see Lemons 2018; Robbins 2018). Are denominational disagreements a product of the Fall? Are prayers answered on the basis of grace alone? Can God be encountered through formal church structures? Should the uncontainable truth of the gospel free the Christian from denominational allegiances? 
My point here is that properly attending to the difference denominations make will require the anthropologist to simultaneously attend to the difference theology makes. This is so insofar as denominationalism is inherently wedded to ecclesiology - and pneumatology, eschatology, and more - not only in the minds (and books) of professional theologians, but also in the minds and everyday lives of many Christians, who, as these papers demonstrate so richly, are often given pause for thought to consider what differences, if any, denominations make in their religious lives. 


\section{Bibliography}

Blom Hansen, T. 2000. 'Predicaments of Secularism: Muslim Identities and Politics in Mumbai' in The Journal of the Royal Anthropological Institute 6(2): 255-272.

Coleman, S. 2000. The Globalization of Charismatic Christianity. Cambridge: Cambridge University Press.

Engelke, M. 2007. The Problem of Presence. Berkeley: University of California Press.

Goffman, E. 1961. Asylums. New York: Anchor Books.

Hann, C. 2007. 'The Anthropology of Christianity per se' in European Journal of Sociology 48(3): 383410.

Haynes, N. 2013. 'On the Potential and Problems of Pentecostal Exchange' in American Anthropologist 115(1): 85-95.

Lemons, D. 2018. Theologically Engaged Anthropology. Oxford: Oxford University Press.

Robbins, J. 2018. Theology and the Anthropology of Christian Life. Stanton Lectures: Faculty of Divinity, University of Cambridge. https://sms.cam.ac.uk/collection/2654114 Accessed 10/10/2018.

Webster, J. 2013. The Anthropology of Protestantism. New York: Palgrave.

Webster, J. 2015. 'Objects of Transcendence: Scots Protestantism and an Anthropology of Things' in Jones, T. W. and Matthews-Jones, L. (eds.) Material Religion in Modern Britain. New York: Palgrave.

Webster, J. Forthcoming. The Religion of Orange Politics. Manchester: Manchester University Press. 